\title{
The Pecking Order Theory: Evidence from Listed Firms in Nigeria
}

\author{
Felix Babatunde Dada \\ University of Wales, GSM PhD Programme, London, UK \\ E-mail: felixdada66@gmail.com
}

Ben Ukaegbu

The Institute of Chartered Accountants of Nigeria, Nigeria

E-mail: felixdada66@gmail.com

Received: Dec. 8, 2015

Accepted: Dec. 19, 2015

Published: Dec. 20, 2015

doi: 10.5296/ifb.v2i2.8679

URL: http://dx.doi.org/10.5296/ifb.v2i2.8679

\begin{abstract}
Pecking order theory of capital structure demonstrates how managers could reduce inefficiency in the presence of information asymmetry in the source of finance. This study aims at a critical evaluation of the relevance of pecking order theory to firms, using the panel data of the listed firms on the Nigerian Stock Exchange. The study adopt the fixed effect model for the determination of the target capital structure and the decision is based on the result of the Hausman test. The study applies the Vector error correction model to establish causality between the variables. The outcome indicates that the capital structure of Nigerian firms is positively related to asset structure while it is negatively related to profitability and liquidity. The study also shows that there is a causal relationship ranging from profitability and liquidity to the capital structure.
\end{abstract}

Keywords: Pecking order theory, Capital structure, Target capital and Partial adjustments 


\section{Introduction}

This study is aimed at an evaluation of Pecking Order theory, using the evidence of listed firms on the Nigerian Stock Exchange (NSE). A panel data of the selected firms for the period between 2008 and 2013 is used in the study for the determination of the relationships between the observed variables.

The pecking order theory is a major development in the field of corporate finance and in particular, the understanding of the concept of capital structure. It was observed that most of the studies on capital structure adopted the positivist approach, this is an indication that studies in this subject have become more empirical. There is also evidence in the development and acceptance of the dynamic capital structure and the process of the capital structure adjustment to the target leverage.

Pecking Order theory is reputed to have been developed from the works of Myers (1984) and Myers \& Majluf (1984). However, their postulation was based on the conviction of Donaldson (1960) that financing practices involve the expectations and that managers would take financial decisions aimed at achieving the reduction in the inefficiency in the organisation as a result of the existence of information asymmetry. Dada (2014) opines that the pecking order theory is a major development on the inadequacies of the 'trade-off theory'.

The pecking order theory evolved from the work of Myers (1984) in the process of explaining the logics of corporate behaviour. It is observed that despite the problems of information asymmetry, the firm is also confronted with the challenges of the optimisation of the performance of the firm. Hence a firm will prefer internal financing sources to any external financing, while the use of debt financing is preferred to the equity financing. It is therefore concluded that the preference of debt finance to equity is a reflection of the effort to reduce the impact of agency problem.

Pecking order theory was made popular by Myer \& Majjluf (1984) when they argue that firms will prefer internal finance to a more risky debt before the issue of equity. This assertion was further established in the work of Myers (2006), when it was observed that in less developed countries with less developed financial system, finance sources are characterised with high level of opaqueness. This feature could force firms to depend on internally generated funds and for external funding needs, they then borrow from banking institutions. This was in line with the findings of Booth et al. (2001) and supported by Sheikh et al. (2011).

Despite the importance of the theory, optimisation of the firm as a theory has not received the desired attention, to the knowledge of these researchers. There is a paucity of research evidence on the evaluation of pecking order theory in developing economies and in particular, Nigeria. This is a major justification for this study as it will attempt to bridge the identified gap. This goal will be achieved with the testing of the relevance of pecking order theory which was developed and tested in the developed economies. The present study will show if this theory is applicable to Nigerian firms and also guide them attain the target capital structure that will optimise the value of the firm. 
Various scholars contributed to the development and the testing of the basic theories of capital structure, such as the pecking-order theory. However, it is observed that most of these theories were formulated following on the conducted research studies executed in developed economies. It is doubtful that these theories are easily applicable in developing countries because of their uniqueness and peculiar financial institutions.

The next section states the objectives of the study. Section three presents a discussion of the literature both the theoretical and the empirical. In Section Four is the statements of research methodology for the study. Section five is the application of the models for the analysis to establish the relationships between the observed variables. The last section is the conclusion.

\section{Objectives of the Study}

This study is aimed at achieving the following objectives which include to:

a. evaluate the pecking order theory using Nigerian listed firms;

b. evaluate the relationship between capital structure and asset structure of Nigerian firms;

c. establish the relationship between capital structure and the firms' performance;

d. evaluate the relationship between capital structure and the firms' liquidity.

\section{Literature Review}

The paper presented by Modigliani \& Miller in 1958 in which the (M \& M) irrelevant hypothesis was proposed. It was proposed that the value of the firm is independent of the capital structure; this irrelevant hypothesis triggered the academics discourse on capital structure that led to Modigliani \& Miller (1963). The 1963 thesis was a correction of fundamental flaw that was discovered in the earlier irrelevant hypothesis. It was therefore postulated that debt finance has tax implications that could impact on the firm's performance and the value of the firm.

The development of the pecking order theory stems from the shift of emphasis by scholars from the static trade off theory toward the dynamic trade off theory. The popularity and the acceptance of the dynamic trade of theory was a major landmark toward the recognition and the appreciation of the pecking order theory hence further discussion of the development in developing economies is required.

Jalilvant \& Harris (1984) brought to attention the concept of capital structure target and the adjustment speed. They observed that company's financial behaviour is informed by partial adjustment to their financial target and that they all strive to achieve the capital structure target with consideration to the adjustment speed of the firm in a particular time period. Fischer et al. (1989) however, emphasised the differences between the maximum and minimum debt ratio over time. It was then noted that the target capital structure could be changed with the associated cost. Havakimain et al. (2001) also discovered, in their study that there is the tendency for firms to take decisions that could lead to change in their target debt ratio over time which they believed will depend on the stock price and their level of 
profitability.

In a comparative study done by Loof (2004) he compare the dynamics of capital structure in different economies and then discovered that deviation from target capital structure is smaller in equity dependent economies such as the United States than financial services (Banking) based economies such as the Swiss economy. Banerjee et al. (2004) and Mukherjee and Mahakud (2010) did extensive study on the dynamics of capital structure with special attention on the determination of the speed of adjustment.

Salawu \& Agboola (2008) observed that asset structure could influence the firm's choice of capital structure and that tangible asset could be used by the firm to reduce the problem of information asymmetry, that tangible assets are less affected by information asymmetries and that the value of firms with tangible assets are higher than the value of firms with intangible assets during the period of bankruptcy and that a firm with more tangible asset posses higher ability to secure debt even at a lower cost. This is made possible with the use of tangible asset as a collateral for the firm's debt, this claim is consistent with Rajan \& Zingala (1995), Kremp et al. (1999), Frank \& Goyal (2002).

Nyamasege et al. (2014) in a capital structure of firms in Kenya claim that large asset base make it easy for the firm to obtain debt, while the tangible asset could increase the lenders and the creditors confident on the firm. This result is consistent with the findings of Frankling \& Muthusamy (2011), Ramjee \& Gwatidzo (2012) and Yadav (2014) that claim that asset tangibility could impact positively on the capital structure of the firm.

Al-Najjar \& Taylor (2008) observe that there is a negative relationship between the firm's profitatability and the capital structure, this claim was based on the fact that the retain earnings of the firm depend of the profitability. This claim is consistent with the results of Donaldson (1960), Myers \& Majluf (1984) and Ramjee \& Gwatidzo (2012), Ezeoha \& Okafor (2010), Mukherjee \& Mahakud (2010), Ajeigbe et al. (2013), Yadav (2014) and Ezeoha (2014).

Sheikh \& Wang (2011) observed that there is negative relationship between capital structure and the firm's liquidity, this claim is based on the pecking order theory that postulates, that high liquidity firms will prefer internal financing instead of the use of external financing of its projects. This claim is consistent with the findings of Panno (2003), Eriotis et al. (2009), Sheikh \& Wang (2011).

\section{Research Methodology}

This study adopts the panel data of selected non financial firms that are listed on the Nigerian Stock Exchange between the period of 2007 and 2013. The selected listed companies are based on the following consideration:

1) The firms with continuous data for the study period

2) The firms that are listed on the Nigerian Stock Exchange for the period of the study

3) The availability of the firm's data on the relevant data base 
The data for the financial fundamentals of the selected companies was obtained from the Orbis database for the standardised information that can be compared globally and this also ensure the integrity and the reliability of the data and the research process due to a significant reduction in data bias. The data not available on the Orbis database is obtained directly from the annual report of the affected companies.

The target capital structure is obtained with the application of fixed effect model, the random effect model and the partial adjustment model as illustrated thus:

$$
L E V_{i t}^{*}=a i+R X i t-1
$$

Where $\mathrm{Xi}_{\mathrm{t}-1}$ is the vector of observed firm characteristics that is the independent variables.

$$
\text { LEVit }=\alpha i+\beta_{1} \text { Prof } t-1_{-1}+\beta_{2} \text { Tang } t-1_{-1}+\beta_{3}{\text { Liqt }{ }_{-1}}+E t
$$

Where:

- $\quad$ LEV $^{*}$ it is the target leverage based on total debt

- Prof is the measure of profitability, this is measured as the earnings after interest and tax per total asset, Prof $=$ EBIT/Total Asset

- Tang is the measure of tangibility, this will be calculated as the total fixed assets per total asset

- $\quad$ Liq is the measure of firm's liquidity

While $\mathrm{t}-1$ is the time dummy variable

The fixed effect could be divided into two components;

The Short-term leverage components that can be represented as;

$$
L E V s^{*}{ }_{i t}=\alpha_{s}+\beta s X_{i t-I}
$$

The long-run leverage conponents that can be represented as;

$$
L E V_{L i t=}^{*} \alpha_{L+} \beta_{L} \text { Xit-I }
$$

The partial adjustment model is formulated to determine dynamic capital structure coefficient using vector error correction model.

$$
L E V=\alpha t+\beta t\left(L E V t^{*}-L E V t-1\right)+\varepsilon t
$$

The causal relationship between capital structure and the observed explanatory variables were evaluated with the adoption of the Vector Error Correction Model. This model determines the short term causality between capital structure and the explanatory variables.

The research hypothesis to be tested in this study are;

H1: There is no causal relationship between asset structure and capital structure.

$\mathrm{H} 2$ : There is no causal relationship between firm's profitability and capital structure. 


\section{Macrothink}

H3: There is no causal relationship between firm's liquidity and capital structure.

\section{Analysis}

This section applies the econometric tool to analyse and simplifies complex relationships between the observed variables, these activities is anchored on the pecking order theory and the formulated model that is translated into the research equations through the research models.

Table 1. Descriptive statistics

\begin{tabular}{|c|c|c|c|c|c|c|}
\hline & LEV & LEVST & LEVLT & TANG & LIQ & PROF \\
\hline Mean & 0.637873 & 0.495489 & 0.145255 & 0.500246 & 1.357078 & 0.099209 \\
\hline Median & 0.598676 & 0.416985 & 0.092818 & 0.494583 & 1.141613 & 0.089852 \\
\hline Maximum & 3.918244 & 3.835919 & 0.997771 & 1.000000 & 7.785115 & 1.291160 \\
\hline Minimum & 0.002353 & 0.000000 & 0.000000 & 0.005934 & 0.000000 & -0.836139 \\
\hline Std. Dev. & 0.363336 & 0.363620 & 0.145310 & 0.231046 & 0.998851 & 0.133010 \\
\hline Skewness & 3.063169 & 3.296722 & 1.813760 & 0.088327 & 2.608093 & 1.074160 \\
\hline Kurtosis & 21.69759 & 23.23991 & 7.806017 & 2.338013 & 13.86021 & 21.62576 \\
\hline Jarque-Bera & 7903.943 & 9251.351 & 740.2410 & 9.584268 & 2963.537 & 7177.160 \\
\hline Probability & 0.000000 & 0.000000 & 0.000000 & 0.008295 & 0.000000 & 0.000000 \\
\hline Sum & 312.5576 & 242.7896 & 71.17486 & 245.1203 & 664.9682 & 48.61265 \\
\hline Sum Sq. Dev. & 64.55436 & 64.65526 & 10.32530 & 26.10397 & 487.8772 & 8.651284 \\
\hline Observations & 420 & 420 & 420 & 420 & 420 & 420 \\
\hline
\end{tabular}

The table above shows the basic feature of the data relating to the selected firms. The mean, median, maximum, minimum a standard deviation of the data was clearly illustrated. While it shows the basic characteristics of the data with the measure of Skewness, Kurtosis, Jarque-Bera and the probability value, which confirm that the data conforms with the principles of normal distribution. The results above indicate that leverage constitutes about 64 percent of the capital structure, while leverage is dominated with short term leverage, as illustrated below; 


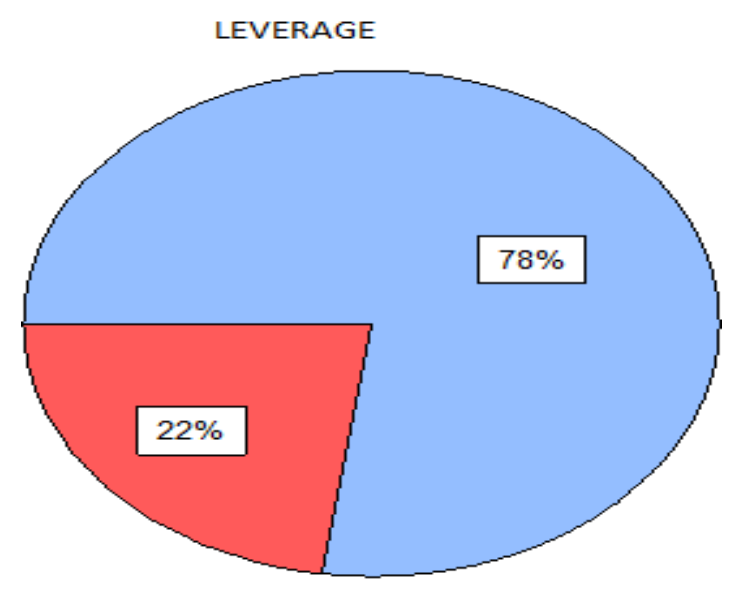

$\square$ LEVST $\square$ LEVLT

Figure 1. Short term and Long term leverage

Figure 1 above illustrates the proportion of short term leverage and the long term leverage in the capital structure of Nigerian non financial firms. It shows that short term leverage is 78 percent of the total leverage while the long term leverage is just a meagre 22 percent of the total leverage, this result shows leverage composition and the challenges of obtaining long term fund for the finance of the firm's activities due to lack of access to long term fund because of the under developed and unstable financial market. The data in this study is tested for autocorrelations and heteroscedasticity.

Table 2. Regression analysis of the dependent and explanatory variables

\begin{tabular}{|c|c|c|c|c|}
\hline Dependent Variable: LEV \\
\hline Variable & Coefficient & Std. Error & t-Statistic & Prob. \\
\hline C & 0.211583 & 0.139637 & 6.528235 & 0.0000 \\
\hline TANG & 0.400898 & 0.063014 & -7.260218 & 0.0000 \\
\hline PROF & -0.162650 & 0.142430 & -0.500416 & 0.6170 \\
\hline LIQ & -0.128277 & 0.014223 & -13.19869 & 0.0000 \\
\hline R-squared & 0.222568 & Mean dependent var & 0.637873 \\
\hline Adjusted R-squared & 0.309867 & S. D. dependent var & 0.363336 \\
\hline S. E. of regression & 0.301839 & Akaike info criterion & 0.462349 \\
\hline Sum squared resid & 43.73116 & \multicolumn{5}{|c|}{ Schwarz criterion } & 0.547949 \\
\hline Log likelihood & -103.2755 & Hannan-Quinn criter & 0.495967 \\
\hline F-statistic & 25.39540 & Durbin-Watson stat & 1.067720 \\
\hline Prob(F-statistic) & 0.000000 & \multicolumn{5}{|}{} \\
\hline
\end{tabular}

The above result shows a positive relationship between leverage and asset structure, while 


\section{Macrothink}

capital structure is negatively related to profitability and firm's liquidity. The relationship with asset structure and liquidity are statistically significant and the relationship with profitability is not statistically significant. This result is consistent with postulations of pecking order theory and supported by Panno (2003), Eriotis et al. (2009), Sheikh \& Wang (2011), Dada (2014) and Dada \& Ukaegbu (2015).

The goodness of fit of the data to the model represented by $\mathrm{R}^{2}$ indicates that 22 percent of the change in the capital structure can be explained by the explanatory variables, this result is accepted as the representation of actual relationship based on the value of probability and F-statistics. The low value of Durbin-Watson statistic led to the evaluation of both fixed effect model and random effect model, the Hausman test was used to determine the appropriate model for this study.

Table 3. Fixed and random effects test comparisons

\begin{tabular}{|c|c|c|c|c|}
\hline Variable & Fixed & Random & Var (Diff.) & Prob. \\
\hline DTANG & 0.400898 & 0.431355 & 0.004603 & 0.6535 \\
\hline DPROF & -0.162650 & -0.106429 & 0.004124 & 0.3813 \\
\hline DLIQ & -0.128277 & -0.150118 & 0.000030 & 0.0001 \\
\hline
\end{tabular}

Table 4. Hausman test

\begin{tabular}{|c|c|c|c|}
\hline \multicolumn{3}{|c|}{ Correlated Random Effects-Hausman Test } & \\
\hline \multicolumn{2}{|c|}{ Equation: Untitled } & & \\
\hline \multicolumn{3}{|c|}{ Test cross-section random effects } & \\
\hline Test Summary & Chi-Sq. Statistic & Chi-Sq. d. f. & Prob. \\
\hline Cross-section random & 34.248936 & 10 & 0.0002 \\
\hline
\end{tabular}

The result above suggests the rejection of the null hypothesis and the acceptance of the alternative hypothesis, which favours the selection of fixed effect model for the analysis. In this study the adoption of the fixed effect model was based on the result of Hausman test that is illustrated above.

The first hypothesis is: There is no short run causality from asset structure to capital structure. 
Table 5. Asset structure and capital structure

\begin{tabular}{|c|c|c|c|}
\hline \multicolumn{2}{|c|}{ Wald Test: } & \\
\hline \multicolumn{3}{|c|}{ Equation: Untitled } & \\
\hline Test Statistic & Value & $\mathrm{d} \mathrm{f}$ & Probability \\
\hline F-statistic & 0.284853 & $(2,463)$ & 0.7523 \\
\hline Chi-square & 0.569706 & 2 & 0.7521 \\
\hline \multicolumn{3}{|c|}{ Null Hypothesis: $\mathrm{C}(2)=\mathrm{C}(3)=0$} & \\
\hline
\end{tabular}

The above table illustrates the test of causality from asset structure to capital structure. The result suggests the acceptance of null hypothesis that $C(2)=C(3)=0$ and the rejection of the alternative hypothesis. Therefore, there is no causal relationship from asset structure to capital structure of Nigerian non financial firms.

The second hypothesis is: There is no short run causality from the firm's profitability to capital structure.

Table 6. Profitability and capital structure

\begin{tabular}{|c|c|c|c|}
\hline \multicolumn{2}{|c|}{ Wald Test: } & \\
\hline \multicolumn{3}{|c|}{ Equation: Untitled } & \\
\hline Test Statistic & Value & $\mathrm{d} \mathrm{f}$ & Probability \\
\hline F-statistic & 2.597076 & $(2,463)$ & 0.0356 \\
\hline Chi-square & 5.194151 & 2 & 0.0345 \\
\hline \multicolumn{3}{|c|}{ Null Hypothesis: $\mathrm{C}(4)=\mathrm{C}(5)=0$} & \\
\hline
\end{tabular}

The above table show the causality between profitability and the capital structure. The result suggests the rejection of the null hypothesis that $\mathrm{C}(4)=\mathrm{C}(5)=0$, not equal to zero and the rejection of the alternative hypothesis. Therefore, there is causal relationship from profitability to the capital structure of Nigerian non financial firms.

The third null hypothesis is: There is no short run causality from the firm's liquidity to capital structure.

Table 7. Liquidity and capital structure

\begin{tabular}{|c|c|c|c|}
\hline \multicolumn{2}{|c|}{ Wald Test: } & \\
\hline \multicolumn{3}{|c|}{ Equation: Untitled } & \\
\hline Test Statistic & Value & $\mathrm{d} \mathrm{f}$ & Probability \\
\hline F-statistic & 0.792302 & $(2,463)$ & 0.0434 \\
\hline Chi-square & 1.584604 & 2 & 0.0428 \\
\hline \multicolumn{3}{|c|}{ Null Hypothesis: $\mathrm{C}(6)=\mathrm{C}(7)=0$} & \\
\hline
\end{tabular}


The above table shows the causal relationship between firm's liquidity and the capital structure. It is observed that, the result suggest the rejection of null hypothesis that $C(6)=C(7)=0$ not equal to zero, while the alternative hypothesis is accepted. This result means that there is causal relationship from liquidity to the capital structure of Nigerian firms.

\section{Conclusion}

The pecking order theory that evolved from the work of Myers (1984) and Myers \& Majluf (1984) opined that a firm prefers to finance its project from internal sources while external sources will be used only when the internal funds from retained earnings is exhausted. This theory, though widely discussed, has not received particular attention in Nigeria because all the efforts had been on the fixed effect model coupled with the used of the relationships which might not translate to causality.

This study achieves its objectives and with the introduction of the vector error correction model, able to established the causal relationship between the pecking order variables, this introduction and the determination of causality is novel to the study of capital structure.

It was observed that the capital structure of Nigerian firm is positively related to asset structure, while it is negatively related to profitability and liquidity. This result is consistent with the postulation of the pecking order theory, this suggests that the pecking order theory is applicable to Nigerian firm. We further observed that there is causal relationship running from profitability and liquidity to the capital structure. While there is no causality from asset structure to the capital structure, this implies that the relationship between asset structure and capital structure does not translate into a causal relationship.

This study could help firms optimise their capital structure and the value of the firms because it could help the concentration of their effort toward the causal variable. It is imperative that the firms should have a shift from short term leverage toward long term leverage in their capital structure as this could enhance their profitability and liquidity.

This study is limited with the problems of generalisation because financial institutions and unlisted firms are excluded from this study, the excluded segment constitute a significant proportion of Nigerian firms.

\section{References}

Abor, J. (2005). The effect of capital structure on profitability: An empirical analysis of listed firms in Ghana. The Journal of Risk Finance, 6(5), 438-445. http://dx.doi.org/10.1108/15265940510633505

Addae, A. A., Nyarko-Baasi, M., \& Hughes, D. (2013). The effect of capital structure on profitability of listed firm in Ghana. European Journal of Business and Management, 5(13), 215-231.

Ajeigbe, K., Fasesin, O., \& Ajeigbe, O. (2013). Nigerian ailing industries and the capital structure: A need for concern. Australian Journal of Business and Management Research, 
3(8), 31-40.

Akinyomi, O., \& Olagunju, A. (2013). Determinants of capital structure in Nigeria. International Journal of Innovation and Applied Studies, 3(4), 999-1005.

Al-Najjar, B., \& Taylor, P. (2008). The relationship between capital structure and ownership structure, new evidence from Jordanian panel data. Managerial Finance, 34(12), 919-933. http://dx.doi.org/10.1108/03074350810915851

Booth, L., Aivazian, V., Dermirguc-kunt, A., \& Maksimovic, V. (2001). Capital structures in developing countries. The Journal of Finance, ivi(1), 87-130. http://dx.doi.org/10.1111/0022-1082.00320

Dada, F. B. (2014). The effects of capital structure on the financial performance of large industrial listed firms in Nigeria. Journal of Developing country studies, 4(10), 122-130.

Dada, F. B., \& Ukaegbu, B. (2015). An evaluation of the Interplay between capital adequacy and capital structure of Nigerian listed Banks. International Journal of Economics, Commerce and Management, 3(11), 113-126.

Donaldson, G. (1961). Corporate debt capacity: A study of corporate debt policy and the determination of corporate debt capacity. Division of Research, Graduate school of Business Administration, Harvard university.

Easterby-Smith, M., Thorpe, R., \& Jackson, P. (2012). Management Research. London: Sage .

Ebaid, I. E. (2009). The impact of capital-structure choice on firm performance: Empirical evidence from Egypt. The Journal of Risk Finance, 10(5), 447-487.

Eriotis, N., Vasiliou, D., \& Ventoura-Neokosinidi, Z. (2007). How firm characteristics affect capital structure: An empirical study. Managerial Finance, 33(5), 321-331. http://dx.doi.org/10.1108/03074350710739605

Ezeoha, A. E. (2014). Firm versus industry financing structures in Nigeria. Africa Journal of Economic and Management Studies, 2(1), 42-55. http://dx.doi.org/10.1108/20400701111110768

Ezeoha, A. E., \& Okafor, F. O. (2010). Local corporate ownership and capital structure decision in Nigeria: a developing country perspective. Corporate Governance, 10(3), 249-260. http://dx.doi.org/10.1108/14720701011051893

Frank, M. Z., \& Goyal, V. K. (2008). Testing the pecking order theory of capital structure. Journal of Financial Economics, $\quad 67(2), \quad$ 217-248. http://dx.doi.org/10.1016/S0304-405X(02)00252-0

Franklin, J., \& Muthusamy, S. (2011). Determinants of financial leverage in Indian pharmaceutical Industry. Asian journal of management, 2(1), 380-395.

Hovakimian, A., Opler, T., \& Titman, S. (2001). The debt-equity choice. Journal of Financial 
and Quantitative Analysis, 36(1), 1-24. http://dx.doi.org/10.2307/2676195

Hovakimian, A., \& Li, G. (2011). In search of conclusive evidence: How to test for adjustment to target capital structure? Journal of Corporate Finance, 17(2), 33-44. http://dx.doi.org/10.1016/j.jcorpfin.2010.07.004

Ramjee, A., \& Gwatidzo, T. (2012). Dynamics in capital structure determinants in south Africa. Meditary Accountancy Research, 20(1), 52-67. http://dx.doi.org/10.1108/10222521211234228

Loof, H. (2004). Dynamic optimal capital structure and technical change. Structural Change and Economic Dynamics, 15(3), 449-468. http://dx.doi.org/10.1016/j.strueco.2003.05.001

Miller, M. H. (1977). Debt and Taxes. Journal of Finance, 32(2), 261-275.

Modigliani, F., \& Miller, M. H. (1958). The cost of capital, corporation finance and the theory of investment. The American Economic Review, xlviii(3), 262-302.

Modigliani, F., \& Miller, M. H. (1963). Corporate income taxes and the cost of capital: A correction. The American Economic Review, 53(3), 433-443.

Mukherjee, S., \& Mahakud, J. (2010). Dynamic adjustment towards target capital structure: Evidence from Indian companies. Journal of Advances in Management Research, 1(2), 250-266.

Myers, S. C. (1984). The capital structure puzzle. Journal of Finance, 39(3), 575-592. http://dx.doi.org/10.2307/2327916

Myers, S. C. (1977). Determinants of corporate borrowing. Journal of Financial Economics, 5(2), 174-175. http://dx.doi.org/10.1016/0304-405X(77)90015-0

Myers, S. C. (2001). Capital Structure. Journal of Economic Perspectives, 15(2), 81-102. http://dx.doi.org/10.1257/jep.15.2.81

Myers, S. C., \& Majluf, M. (1984). Corporate financing and investment decisions when enterprises have information Investors do not have. Journal of Finance, 13(2), 187-221.

Nyamasege, D., Okibo, W., Nyangau, A., Sangania, P., Omosa, H., \& Momanyi, C. (2014). Effect of asset structure on value of a firm: A case of companies listed in Nairobi Securities Exchange. Research Journal of Finance and Accounting, 5(7), 205-212.

Panno, A. (2003). An empirical investigation on the determinants of capital structure: The UK and Italian experience. Applied Financial Economics, 13(2), 97-112. http://dx.doi.org/10.1080/09603100210100882

Rajan, G., \& Zingales, L. (1995). What do we know about capital structure? Some evidence from international data. Journal of Finance, 50(1), 1421-1460. http://dx.doi.org/10.1111/j.1540-6261.1995.tb05184.x

Ramjee, A., \& Gwatidzo, T. (2012). Dynamics in capital structure determinants in south Africa. Meditary Accountancy Research, 20(1), 52-67. 
http://dx.doi.org/10.1108/10222521211234228

Salawu, R. O. (2007). An empirical analysis of the selected quoted companies in Nigeria. The International Journal of Applied Economics and Finance, 1(1), 16-28. http://dx.doi.org/10.3923/ijaef.2007.16.28

Salawu, R. O., \& Agboola, A. A. (2008). The determinants of capital structure of large non-financial listed firms in Nigeria. The Journal of Business and finance Research, 2(2), 75-84.

Saunders, M., Lewis, P., \& Thornhill, A. (2007). Research Method for business Students (4th ed.). London: Prentice Hill.

Sheikh, N. A., \& Wang, Z. (2011). Determinants of capital structure, an empirical study of firms in manufacturing industry in Pakistan. Managerial Finance, 37(2), 117-133. http://dx.doi.org/10.1108/03074351111103668

Thomas, G. (2012). How to do your research project (8th ed.). London: Sage.

Yadav, C. S. (2014). Determinants of the capital structure and financial leverage: Evidence of selected Indian companies. Asia Pacific Journal of Research, 1(12), 121-131.

\section{Copyright Disclaimer}

Copyright for this article is retained by the author(s), with first publication rights granted to the journal.

This is an open-access article distributed under the terms and conditions of the Creative Commons Attribution license (http://creativecommons.org/licenses/by/3.0/). 